\title{
EFFECTIVENESS OF STRUCTURED-WORKSHEET USE TO REDUCE STUDENT MISCONCEPTIONS IN STOICHIOMETRY
}

\author{
Irma Ayu Virtayanti ${ }^{\star *}$ and Rosyidah Syafaatur Rohmah ${ }^{1}$ \\ ${ }^{1}$ Departement of Chemistry Education, Billfath University, PP AlFattah Siman \\ Foundation, Lamongan, 62260, Indonesia \\ *E-mail: Irma.virtayanti@gmail.com
}

Received: 20 October 2020; Accepted: 08 November 2020; Published: 31 December 2020

\begin{abstract}
This study aims to describe the effectiveness of Structured Problem-oriented worksheets (Structured Worksheet) in reducing misconceptions of $2^{\text {th }}$ Senior High School Lamongan students in the 2019/2020 Academic Year. This study involved 19 students from $2^{\text {th }}$ Senior High School Lamongan. The effectiveness measured by three indicators consist of: the level of mastery learning of students after Learning Activity Using Structured Worksheet; reduction of students' misconceptions; and student response questionnaire. Data obtained from learning outcome tests were included in the learning outcomes analysis format. Diagnostic test data were analyzed using descriptive statistics to find out what percentage of students experience misconceptions. Student response data in the form of satisfaction and motivation questionnaires were analyzed descriptively. The results showed that the average level of student learning completeness was 93 and was above the Standard Minimum Score of 80 . The percentage of concept errors experienced by students on stoichiometry material decreased to $98 \%$. Based on the questionnaire given, $89.5 \%$ of students have high satisfaction with stoichiometry learning using Structured Worksheet. As much as $78.9 \%$ of students have a high level of learning motivation. Based on the results, applying a Structured Worksheet in learning effectively reduces students' misconceptions in stoichiometry.
\end{abstract}

Keywords: effectiveness, misconception, stoichiometry, structured worksheet

DOI: http://doi.org/10.15575/jtk.v5i2.9873

\section{INTRODUCTION}

Chemistry is one of the branches of natural sciences that requires understanding of concepts and mathematical by students (Ariyaldi, 2017). One of the subject matter of chemistry taught in high school is the calculation of chemistry called stoichiometry. This subject is given to the tenth grade students of high school. Stoichiometry contains not only theoretical but also chemical calculations.

In stoichiometry, students not only required to be able to complete chemical calculations, but also connect the basic concepts that have been obtained and apply in the chemical calculation concept. If the students master mathematics calculation, then the students will not have any significant difficulty in solving the problem of chemical calculation. In addition to mastering that, students are also required to master the concept of moles as a basic ability to learn stoichiometry. This was supported by Bou Jaoude and Barakat who stated that students' mathematical expertise also contributes to their difficulties. A student who cannot manipulate numbers readily is unlikely to be successful in learning about moles" (Kind, 2004). This is the reason that stoichiometry is not an easy topic because it is complex and complicated material. If students do not understand this material well, then students will be constrained to master the next materials. Stoichiometry is a basic concept of 


\section{I.A. Virtayanti \& R.S. Rohmah}

chemistry that requires understanding qualitative and quantitative aspects related to chemical phenomena to solve various chemical problems in high schools and colleges (Sunyono, 2015). Stoichiometry is a chemical calculation that must be understood correctly because it underlies other chemical concepts, namely moles, chemical equilibrium (Jusniar et al., 2019)

Based on the results of interviews with several chemistry teachers and students, it is known that students have difficulty in understanding the material because many concepts are abstract and mathematical calculations that make students confused. Misconceptions perhaps highly resistant to change, fixed for years, and unaffected by classroom teaching (Luoga et al., 2013). Therefore, analysis is carried out through pre-test to find out whether the students' concept of stoichiometry is correct or not.

Previous research has shown that students have difficulty understanding stoichiometry (Furio et al., 2002). Such difficulties can cause students to encounter misconception in stoichiometry (Nilawati, 2016) A misconception is a mismatch of students' understanding of science agreed upon by scientists (Barke et al., 2009; Mondal, B. et al., 2013). Misconception can be caused by teacher explanations, textbooks, and students' prior knowledge (Jusniar et al., 2019; Kelly et al., 2019).

Research on stoichiometry misconceptions has been widely done. A common mistake of students in stoichiometry is the use of chemical symbol and the calculation of the number of ratios (Glažar, S., 2002). Nilawati et al. (2016) have found that misconceptions were experienced by high school students in grade $X$, including: calculation of relative mass based on the number of molecules that make up the compound; relative mass has gram/mole units; particles used to compose compounds in the form of atoms and or molecular elements; particles of a compound are the constituent elements of the compound; molar mass has gram units and microscopic images of molecular compounds in the form of

\section{Effectiveness of Structured-Worksheet Use to Reduce Student Misconceptions in Stoichiometry}

ions; 1 mole is the mass of NA gram substance that. Jusniar et al (2019) stated concept errors experienced by students in grade eleven of Senior High School 2 Gowa, consist of: the number of moles of the reagent and the product is equal to the number of element indexes in the substance; the number of substance moles is an inverse comparison with the reaction coefficient; dissociation reaction is the bond-breaking reaction among molecules; increased concentration increases the surface area so that the number of effective collisions increases; in exothermic reactions there is an increase in the enthalpy of the reactions (Luoga et al., 2013). Kelly et al (2019) examined the misconception of high school students in Swaziland, namely error in equalizing reaction equations.

One alternative solution to overcome learning difficulties and misconceptions is to use teaching materials in the form of student worksheets. Worksheet is a vital instrument in supporting learning activities, both groups and individuals, and questions written on the worksheet (Prastowo, 2014). The use of worksheet in chemical learning is very commonly aplicated. Students' ability to find concepts of electrolyte and non-electrolyte solutions in learning using Inductiveworksheet reached an average of $91.17 \%$ (Virtayanti et al., 2018). In addition, students' ability to understand the concept of electrolyte and non-electrolyte solutions in learning using Inductive-worksheet reached an average of $91.91 \%$ which is classified to an excellent category (Virtayanti et al., 2018). This shows that by using worksheet the ability of students to find their own concepts to be achieved has been very good. Virtayanti (2017) on the development of science generic skill-orientedworksheet in chemical equilibrium learning concluded that the increased understanding of the concept of chemical equilibrium of students before and after learning is classified into a high category with an average N-Gain of 0.85 .

Deyanti (2008) mentioned that worksheet is divided into two, namely unstructuredworksheet and structured-worksheet. Unstructured-worksheet is a means to support

Jurnal Tadris Kimiya 5, 2 (December): 195-203

This is an open access article under CC-BY-SA license (https://creativecommons.org/licenses/by-sa/4.0/) 


\section{I.A. Virtayanti \& R.S. Rohmah}

learning materials as a source of student learning activities used by teachers to deliver learning. Structured-worksheet is a worksheet designed to guide students in a lesson work program with little help from the teacher to achieve the intended goals in the learning (Deyanti, 2008)

Structured test-oriented worksheet is an worksheet designed in such a way that in learning, students gain their knowledge and understanding independently and structured. Structured test-oriented worksheet (structured-worksheet) is designed to guide students to correct student misconceptions.

Based on the explanation above, it is necessary to review the effectiveness of the use of Structured-worksheet to reduce student misconceptions in stoichiometry. Therefore, the researchers wanted to conduct a study with the title Effetiveness of structuredworksheet use to reduce student misconceptions in stoichiometry.

\section{RESEARCH METHODS}

\subsection{Research Design}

The research design used in this study is a descriptive analysis that is the design of research that seeks to describe a symptom of a phenomenon or event systematically and accurately and in depth. In the research, descriptive design is used to describe $2^{\text {th }}$ Senior High School Lamongan students learning outcomes which is taught by using structured-worksheet in stoichiometry.

\subsection{Place and Time of Research}

The research was conducted at $2^{\text {th }}$ Senior High School Lamongan for the 2019/2020 academic year. The object of research is stoichiometry in chemistry lessons. This is based on pre-research results which show that most students have difficulty with stoikiometric material.

\subsection{Stages of Research}

The research stage consists of three stages, namely pre-research, identification of misconceptions, overcoming misconceptions by applying structured-worksheet teaching
Effectiveness of Structured-Worksheet Use to

Reduce Student Misconceptions in

Stoichiometry

materials. The research planning sequences are described below.

\subsubsection{Pre-Research}

Pre-research was carried out with the aim of knowing the preliminary overview of chemicals that became difficult for most students. Preresearch was conducted by interviewing several teachers and students. After knowing the preliminary overview of the pre-research results, the preparation of research proposal proposals and arranging instruments is carried out.

\subsubsection{Identification of Misconceptions}

Pre-research results showed that most students had difficulty in understanding stoichiometry. The percentage of misconceptions of students experienced in stoichiometry was identified using stoichiometry diagnostic test instruments.

\subsubsection{Overcoming Misconceptions by Applying structured-worksheet Based Teaching Materials}

The purpose of this section is to determine the effectiveness of the use of structuredworksheet based teaching materials to reduce student misconceptions in stoichiometry. As for knowing the effectiveness measured by three indicators, namely:

a. Level of student learning completeness after learning activities using structuredworksheet based teaching materials. The instrument used is a written test given after teaching and learning activities.

b. Reduction of student misconceptions. Instruments in the form of written tests.

c. Student response to learning using structured-worksheet based teaching materials. The instrument used is a questionnaire of students' response to learning using structured-worksheetbased teaching materials.

The instrument is given after teaching and learning activities.

\subsection{Research Variables}

The research variables analyzed are:

a. Level of student learning completeness after teaching and learning activities.

Jurnal Tadris Kimiya 5, 2 (December): 195-203

This is an open access article under CC-BY-SA license (https://creativecommons.org/licenses/by-sa/4.0/) 


\section{I.A. Virtayanti \& R.S. Rohmah}

b. Misconceptions experienced by students of $2^{\text {th }}$ Senior High School Lamongan on stoichiometry.

c. Students' response to learning using structured-worksheet-based teaching materials.

\subsection{Data Analysis Techniques}

Research instruments in the form of multiple choice test questions consisting of 23 questions. Before being used to retrieve data, feasibility and validation trials are conducted in the form of content validation and reliability. In addition, the structured-worksheet instrument is validated by 3 experts, with expert assessment results used as the basis for determining the validity of the content using Aiken's V formula (Aiken, 1985). The formula is used to calculate the coefficient of the validity of the fill with the following equation:

Explanation:

$$
V=\Sigma s /[n(c-1)]
$$

$s=r-10$

lo $=$ lowest validity assessment number

$\mathrm{C}=$ highest validity assessment number

$r=$ number given by the assessor.
Effectiveness of Structured-Worksheet Use

to Reduce Student Misconceptions in Stoichiometry

\subsubsection{Data Analysis of Test Results}

Data obtained from the study results test is included in the format of analysis of learning results, then each student is given a score with the following determinations.

$$
\% \text { achievement }=\frac{\text { amount achieved by students }}{\text { Total score of all questions }} \times 100 \%
$$

Students are said to complete their learning if they achieve greater grades equal to the minimum completion criteria.

\subsubsection{Reduction of Misconceptions}

Calculation of the effectiveness of structuredworksheet (E) from student misconception data as follows.

$$
E=\frac{\text { pre }- \text { test percentage }- \text { postest percentage }}{\text { pre }- \text { test percentage }} \times 100 \%
$$

Effective if the value of $E \geq 31 \%$ (Ansori, 2018)

\subsubsection{Analysis of Student Response Data} Student response data in the form of satisfaction and motivation questionnaires were analyzed descriptive
Effectiveness of the Use of Structured-Worksheet-Based Teaching Materials to Reduce Misconceptions of Students of $2^{\text {th }}$ Senior High School Lamongan on Stoichiometry

Step 1

Identification of misconceptions (knowing the percentage of misconceptions that students make on stoichiometry)

\section{Step 2}

Apply structured worksheet-based teaching materials. This stage aims to determine the effectiveness of using structured worksheets

\begin{tabular}{|l|l|}
\hline $\begin{array}{l}\text { Students' learning completion after learning } \\
\text { activities using structured-worksheet }\end{array}$ & $\begin{array}{l}\text { Students' response to learning using } \\
\text { structured worksheet }\end{array}$ \\
\hline $\begin{array}{l}\text { Test instruments of learning results (after the } \\
\text { teaching and learning process) }\end{array}$ & $\begin{array}{l}\text { Student satisfaction questionnaire instrument (given } \\
\text { after the teaching and learning process) }\end{array}$ \\
\hline
\end{tabular}

Figure 1. Research Flow 


\section{I.A. Virtayanti \& R.S. Rohmah}

\section{RESULT AND DISCUSSION}

The results of the test question are as follows: validity of content of $91 \%$ and reliability of multiple choice of 0.72 which means it is feasible to use. In addition, expert assessment scores on structuredworksheet are used to calculate the coefficient of content validity using Aiken's $\mathrm{V}$ formula. From the calculation result obtained the coefficient of content validity of 0.82 which means that the worksheet is valid or adequate with a slight revision in some parts.

\subsection{Test Results}

The average cognitive score on stoichiometry increased after students carried out structured-worksheet assisted teaching and learning activities. The final test results showed an average score of 93 with the lowest score on the final test result was 83 , while the minimum completion criteria score was 80 . Because the lowest score on the final test is greater than the minimum completion criteria, it can be ascertained that all students in grade 11 of $2^{\text {th }}$ Senior High School Lamongan on stoichiometry had learning completion after being taught using structured-worksheet assisted learning.

\subsection{Reduction of Misconceptions}

Test results showed that there were 15 student misconceptions that appeared before learning. Previous research has also shown that there were 16 misconceptions in stoichiometry experienced by students (Aini, 2016). This means that there are still many concepts that students do not understand properly. However, after learning using structured-worksheet, students had a decrease in misconceptions in stoichiometry to 1 misconception. Details of misconceptions shown in Table 1.

\section{Table 1. Details student misconceptions}

\begin{tabular}{|c|l|c|c|c|}
\hline $\begin{array}{c}\text { Num } \\
\text { ber }\end{array}$ & \multicolumn{1}{|c|}{ Misconception } & $\begin{array}{c}\% \\
\text { Pretest }\end{array}$ & $\begin{array}{c}\% \\
\text { Posttest }\end{array}$ & $\mathrm{E}$ \\
\hline 1 & $\begin{array}{l}\text { Students assumed } \\
\text { calculating relative } \\
\text { mass based on the } \\
\text { number of } \\
\text { compound }\end{array}$ & 5 & 0 & 100 \\
\hline
\end{tabular}

Effectiveness of Structured-Worksheet Use to Reduce Student Misconceptions in Stoichiometry

\begin{tabular}{|c|c|c|c|c|}
\hline $\begin{array}{c}\text { Num } \\
\text { ber }\end{array}$ & Misconception & $\begin{array}{c}\% \\
\text { Pretest }\end{array}$ & $\begin{array}{c}\% \\
\text { Posttest }\end{array}$ & $\mathrm{E}$ \\
\hline & $\begin{array}{l}\text { constituent } \\
\text { molecules }\end{array}$ & & & \\
\hline 2 & $\begin{array}{l}\text { Students assumed } \\
\text { the relative mass to } \\
\text { be a mass of } 1 \text { mole }\end{array}$ & 11 & 0 & 100 \\
\hline 3 & $\begin{array}{l}\text { Students assumed } \\
\text { the relative mass to } \\
\text { have gram } / \text { mole unit }\end{array}$ & 11 & 0 & 100 \\
\hline 4 & $\begin{array}{l}\text { Students assumed } \\
\text { the relative mass to } \\
\text { have a gram unit }\end{array}$ & 5 & 0 & 100 \\
\hline 5 & $\begin{array}{l}\text { Students assumed } \\
\text { the relative mass to } \\
\text { have a unit of } \\
\text { atomic mass unit }\end{array}$ & 5 & 0 & 100 \\
\hline 6 & $\begin{array}{l}\text { Students assumed } \\
\text { molecular/covalent } \\
\text { compound particles } \\
\text { to be ions }\end{array}$ & 16 & 5 & 67 \\
\hline 7 & $\begin{array}{l}\text { Students assumed } 1 \\
\text { gram of compound } \\
\text { contains a } \\
\text { molecular amount of } \\
\text { relative molecular } \\
\text { mass of compound } \\
\text { molecules }\end{array}$ & 5 & 0 & 100 \\
\hline 8 & $\begin{array}{l}\text { Students assumed } \\
\text { the constituent } \\
\text { particles of } \\
\text { compounds in the } \\
\text { form of atoms and } \\
\text { or molecules of the } \\
\text { constituent } \\
\text { elements }\end{array}$ & 32 & 0 & 100 \\
\hline 9 & $\begin{array}{l}\text { Students assumed } \\
\text { the unit of molar } \\
\text { mass of the } \\
\text { substance is grams }\end{array}$ & 11 & 0 & 100 \\
\hline 10 & $\begin{array}{l}\text { Students assumed } \\
\text { molar masses to } \\
\text { have gram units and } \\
\text { microscopic } \\
\text { representations of } \\
\text { molecular } \\
\text { compounds in the } \\
\text { form of ions }\end{array}$ & 5 & 0 & 100 \\
\hline 11 & $\begin{array}{l}\text { Students assumed } \\
\text { molar masses to } \\
\text { have units of atomic } \\
\text { mass units and } \\
\text { microscopic } \\
\text { representations of } \\
\text { molecular } \\
\text { compounds in the } \\
\text { form of ions }\end{array}$ & 5 & 0 & 100 \\
\hline 12 & $\begin{array}{l}\text { Students assumed } 1 \\
\text { mole of the } \\
\text { compound to } \\
\text { contain } 1 \text { particle of } \\
\text { the compound }\end{array}$ & 5 & 0 & 100 \\
\hline 13 & $\begin{array}{l}\text { Students assumed } \\
\text { the particle types of } \\
\text { each substance to } \\
\text { be the same }\end{array}$ & 5 & 0 & 100 \\
\hline
\end{tabular}

Jurnal Tadris Kimiya 5, 2 (December): 195-203

This is an open access article under CC-BY-SA license (https://creativecommons.org/licenses/by-sa/4.0/) 


\section{I.A. Virtayanti \& R.S. Rohmah}

\begin{tabular}{|c|l|c|c|c|}
\hline $\begin{array}{c}\text { Num } \\
\text { ber }\end{array}$ & \multicolumn{1}{|c|}{ Misconception } & $\begin{array}{c}\% \\
\text { Pretest }\end{array}$ & $\begin{array}{c}\% \\
\text { Posttest }\end{array}$ & E \\
\hline 14 & $\begin{array}{l}\text { Students assumed } \\
\text { the number of moles } \\
\text { to be the same so } \\
\text { that it has the same } \\
\text { molar mass }\end{array}$ & 11 & 0 & 100 \\
\hline 15 & $\begin{array}{l}\text { Students consider 1 } \\
\text { mole to be a gram } \\
\mathrm{N}_{\mathrm{A}} \text { mass of the } \\
\text { substance }\end{array}$ & 11 & 0 & 100 \\
\hline & & Average & 98 \\
\hline
\end{tabular}

The average effectiveness of structuredworksheets (E) from student misconception data showed a score of $98 \%$ greater than $31 \%$. The results showed that structured worksheet-assisted learning effectively reduced the tendency of misconceptions experienced by students.

Some of the misconceptions experienced by students in this study are in line with previous research. For example, students initially continued to write units at relative atomic mass. In line with Roikah's research (2013), stated that $\mathrm{gram} / \mathrm{mole}$ is units of relative atomic mass. This is not in accordance with the theory that the relative molecular mass and relative atomic mass have no unit because it is a comparison between the mass of the substance and the mass of $1 / 12$ atom C-12 (Roikah, 2013).

In addition, students initially considered particles of an ionic compound to be the constituent elements of the compound. This is also in line with previous research, students state that ionic compounds are composed of molecules (Aini, 2016). The correct concept states that ionic compounds do not contain molecules, ionic compounds are composed of ions (Brady, 1999).

Students consider the mass to be comparable to the coefficient. The correct concept states that the reaction coefficient is comparable to the number of moles and volume, not the mass of the compound. This is in line with previous research which stated that students consider the coefficient comparison to be a mass comparison (Wahyuni, Eka, 2010).
Effectiveness of Structured-Worksheet Use to Reduce Student Misconceptions in Stoichiometry

\subsection{Student Response Data Analysis}

The criteria for student learning satisfaction level are presented in table 2 below.

Table 2. Student Learning Satisfaction Level Criteria

\begin{tabular}{|c|c|c|c|}
\hline $\begin{array}{c}\text { Score } \\
\text { range }\end{array}$ & $\begin{array}{c}\text { Number of } \\
\text { students }\end{array}$ & $\%$ & $\begin{array}{c}\text { Learning } \\
\text { satisfaction } \\
\text { criteria }\end{array}$ \\
\hline $45-60$ & 17 & 89.5 & High \\
\hline $30-44$ & 2 & 10.5 & Medium \\
\hline $15-29$ & 0 & 0 & Low \\
\hline
\end{tabular}

Based on these result, it is known that $89.5 \%$ students have high satisfaction with stoichiometry learning using structured worksheet, and $10.5 \%$ students have moderate/sufficient level of learning satisfaction. This means that students have an excellent level of learning satisfaction during stoichiometry learning using structuredworksheet. The criteria/classification of students' learning motivation level are presented in Table 3 as follows.

Table 3. Students' Learning Motivation Level

\begin{tabular}{|c|c|c|c|}
\hline $\begin{array}{c}\text { Score } \\
\text { range }\end{array}$ & $\begin{array}{c}\text { Number of } \\
\text { students }\end{array}$ & $\%$ & $\begin{array}{c}\text { Learning } \\
\text { motivation } \\
\text { level }\end{array}$ \\
\hline $123-151$ & 15 & 78.9 & High \\
\hline $91-122$ & 4 & 21.1 & Medium \\
\hline $59-90$ & 0 & 0 & Low \\
\hline
\end{tabular}

Based on table 3, it is known that $78.9 \%$ of students have a high level of learning motivation and $21.1 \%$ of students have a moderate level of learning motivation. This means that students have excellent learning motivation in stoichiometry learning using structured-worksheet.

The results showed that structuredworksheet-assisted learning effectively reduced the tendency of misconceptions experienced by students. 


\section{CONCLUSION}

The results showed that the level of student learning completedness was at an average of 93 and higher than the minimum completion criteria of 80 . The average effectiveness of structured worksheet (E) from student misconception data shows a score of $98 \%$ greater than $31 \%$. The questionnaire given to students showed that $89.5 \%$ of students had high satisfaction with stoikiometric learning using structured-worksheet and as many as $78.9 \%$ of students had a high level of learning motivation. Implementation of structuredworksheet-assisted learning is effective to reduce student misconceptions in stoichiometry. 


\section{I.A. Virtayanti \& R.S. Rohmah}

\section{REFERENCES}

Aiken, L. R. (1985). Three Coefficients for Analyzing the Reliability of Single Items or Questionnaires. Educational and Psychological Measurement.

Aini, R. G., Ibnu, S., Budiarsih, E. (2016). Identifikasi Miskonsepsi dalam Materi Stoikiometri pada Siswa Kelas X Di SMAN 1 Malang Melalui Soal Diagnostik Three-Tier. Jurnal Pembelajaran Kimia (J-PEK) 1(2), 50-56. Retrieved from http://journal2.um.ac.id/index.php/jpek/article/view/769

Ansori, Y. N. (2015). Pengembangan Modul Larutan Buffer Berdasarkan Persepsi Konsep Sukar dan Kesalahan Konsep dengan Model Daur Belajar 3 Fase untuk Matakuliah Kimia Dasar II. Tesis Tidak Diterbitkan. Malang: FMIPA-UM.

Ariyaldi, Putri, A. T., Khalisah, A. N., \& Nurhikma. (2017). Pengaruh Penggunaan Strategi Dynamic Problem Solving Berbasis Conceptual Scaffolding untuk Meningkatkan Hasil Belajar dan Aktivitas Belajar Peserta Didik pada Materi Sifat Koligatif Larutan. Jurnal Nalar Pendidikan, 5(2), 158-164. https://doi.org/10.26858/jnp.v5i2.4875

Barke, H., Azhari, A., \& Yitbarek, S. (2009). Misconceptions in Chemistry. Berlin: Springer.

Brady, J. E. (1999). Kimia Universitas: Asas dan Struktur. Jakarta: Binarupa Aksara.

Deyanti, N. P. (2008). Implementasi Model Pembelajaran Learning Cycle " $5 E$ " Berbantuan Worksheet Terstruktur untuk Meningkatkan Kemampuan Penalaran dan Komunikasi Matematika Siswa Kelas VIIIA SMP Negeri 6 Singaraja Laporan Penelitian. (Tidak Diterbitkan). Universitas Pendidikan Ganesha.

Furio, C., Azcona, R., \& Guisasola, J. (2002). The Learning and Teaching of the Concepts 'Amount of Substance' and
Effectiveness of Structured-Worksheet Use to Reduce Student Misconceptions in Stoichiometry

'Mole': A Review of the Literature. Chemistry Education: Research and Practice in Europe, 3(3), 277-292. https://doi.org/10.1039/B2RP90023H

Glažar, S., \& Devetak, I. (2002). Secondary School Students' Knowledge of Stoichiometry. Acta Chimica Slovenica, 49, 43-53. Retrieved from https://www.researchgate.net/profile/lzto k_Devetak/publication/290170776_Seco ndary_school_students'_knowledge_of_s toichiometry/links/5759582b08ae414b8e 43aa57/Secondary-school-studentsknowledge-of-stoichiometry.pdf

Jusniar, Budiasih, E., Effendi, \& Sutrisno. (2019). The Misconception of Stoichiometry and Its Impact on the Chemical Equilibrium. 1st International Conference on Advanced Multidiscpilinary Research (pp. 138-141). Atlantis Press.

Kelly, V., Oloyede, O. I., \& Mkhumane, E. (2019). An Investigation Into Misconceptions Held by Secondary School Chemistry Student (Study in Stoichiometry and the Mole). International Journal of Biology, Physics \& Matematics, $2(1), 82$ - 97.

Kind, V. (2004). Beyond Appearances: Students' Misconceptions about Basic Chemical Ideas 2nd Edition. Amerika Serikat: School of Education Durham University Durham DH1 1TA.

Luoga, N. E., Ndunguru, P. A., \& Mkoma, S. L., (2013). High School Students' Misconceptions about Colligative Properties in Chemistry. Tanzania Journal of Natural \& Applied Sciences, 4(1), 575-581. Retrieved from https://www.semanticscholar.org/paper/H igh-school-students\%27-misconceptionsabout-in-Luoga-

Ndunguru/44d7a38015a3e0d54ebd3d92 c6e53a29cc3b590d 
Effectiveness of Structured-Worksheet Use to Reduce Student Misconceptions in Stoichiometry

Mondal, B., \& Chakraborty, A. (2013). Misconceptions in Chemistry: Its Identification and Remedial Measures. Germany: LAP Lambert Academic Publishing.

Nilawati, P., Subandi, \& Utomo, Y. (2016). Keefektifan Pembelajaran Interkoneksi Multipel Representasi dalam Mengurangi Kesalahan Konsep Siswa pada Materi Stoikiometri. Jurnal Pendidikan: Teori, Penelitian, dan Pengembangan, 1(11), 2076-2082.

http://dx.doi.org/10.17977/jp.v1i11.7773

Prastowo, A. (2014). Pengembangan Bahan Ajar Tematik. Jakarta: Karisma Putra Utama.

Roikah, R. (2013). Identifikasi Persepsi Konsep Sukar dan Kesalahan Konsep Mol dan Tetapan Avogadro pada Siswa Kelas XI IPA SMAN 2 Malang Tahun Ajaran 2012-2013. Skripsi. Program Studi Pendidikan Kimia Jurusan Kimia FMIPA Universitas Negeri Malang.

Sunyono, Yuanita, L., \& Ibrahim, M. (2015). Mental Models of Students on Stoichiometry Concept in Learning by Method Based on Multiple Representation. The Online Journal of New Horizons in Education, 5 (2), 30-45. Retrieved from http://repository.Ippm.unila.ac.id/6332/

Virtayanti, I. A., Abudarin, \& Wijayanti, E. (2017). Pengembangan Lembar Kerja Siswa Berorientasi Keterampilan Generik Sains Dalam Pembelajaran Kesetimbangan Kimia (Studi di SMAN 4 Palangka Raya). Prosiding Seminar Nasional Kimia dan Pendidikan Kimia, FKIP, Universitas Sebelas Maret, 22 April 2017. 92-99. Surakarta: Universitas Sebelas Maret.

Virtayanti, I.A, Abudarin, \& Sadiana, I Made, (2018). Kemampuan Siswa Menemukan dan Memahami Konsep Larutan Elektrolit Menggunakan Worksheet-Induktif. Jurnal

Tadris Kimiya, 3(2), 104-113. https://doi.org/10.15575/jtk.v3i2.2707

Wahyuni, E. (2010). Identifikasi Konsep Sukar dan Salah Konsep dalam Pokok Bahasan Perhitungan Kimia pada Siswa SMA Negeri 8 Malang. Skripsi. Program Studi Pendidikan Kimia Jurusan Kimia FMIPA Universitas Negeri Malang. 